\title{
Levodropropizine for treating cough in adult and children: a meta-analysis of published studies
}

\author{
Alessandro Zanasi ${ }^{1 *}$, Luigi Lanata ${ }^{3}$, Giovanni Fontana ${ }^{2}$, Federico Saibene ${ }^{3}$, Peter Dicpinigaitis ${ }^{5}$ \\ and Francesco De Blasio ${ }^{4}$
}

\begin{abstract}
Background: Cough is one of the most common symptoms for which patients seek medical attention from primary care physicians and lung specialists. About $40 \%$ of the population at any one time report cough. Cough is associated with significantly impaired health-related quality of life. Levodropropizine is an effective and very well tolerated peripheral antitussive drug. We want to compare it to central cough suppressants efficacy (opioids and non-opioids) that may be associated with side effects limiting their use.

Methods: After a comprehensive literature search, a meta-analysis of 7 clinical studies of levodropropizine vs. control, including a total of 1,178 patients, was performed with the aim to evaluate the overall comparative efficacy of levodropropizine in the pediatric and adult population.

Three electronic databases and reference list were used to search for studies that assessed the efficacy of levodropropizine for treating cough in children and adults using as standardized efficacy parameters the cough frequency and severity, and number of night awakenings as outcome parameters.

Results: The meta-analysis of all standardized efficacy parameters showed a highly statistically significant difference in the overall antitussive efficacy in favor of levodropropizine vs. control treatments $(p=0.0015)$.

The heterogeneity test for the efficacy outcome was not statistically significant $(p=0.0534)$.

Seven studies met out inclusion criteria. A meta-analysis of the eligible ones showed a statistically significant difference in the overall anti-tussive effect of levodropropizine versus control ( $p=0.0015)$.

Conclusions: This analysis indicates that levodropropizine is an effective antitussive drug in children and adults, with statistically significant better overall efficacy outcomes vs. central antitussive drugs (codeine, cloperastine, dextromethorphan) in terms of reducing cough intensity and frequency, and nocturnal awakenings. This result further reinforces the favorable benefit/risk profile of levodropropizine in the management of cough. The efficacy of levodropropizine in the treatment of cough in children and adults is higher than that of the common centrally-acting anti-tussive.
\end{abstract}

\section{Background}

Cough is one of the most common symptoms for which patients seek medical attention from primary care physicians and lung specialists [1]. In epidemiologic studies, up to $40 \%$ of people at any one time report cough [2].

Clinically, the etiology of cough can be broadly classified into acute and chronic as deduced from the length of time it persists, acute cough lasting from 1 to 3 weeks and chronic cough lasting more than 8 weeks. The most

\footnotetext{
* Correspondence: alessandro.zanasi@aosp.bo.it

${ }^{1}$ Pneumology Unit, University of Bologna, S. Orsola Malpighi Hospital, Bologna, Italy

Full list of author information is available at the end of the article
}

frequent causes of acute cough are viral or bacterial upper respiratory tract infections (URTIs), while those of chronic cough are asthma, gastro-esophageal reflux disease (GERD), chronic rhinitis, chronic bronchitis, chronic obstructive pulmonary disease (COPD), ACE-inhibitors treatment [3].

Regardless of whether it is acute or chronic, cough is associated with significantly impaired health-related quality of life, as sleep disturbance, nausea, chest pain and lethargy frequently occur [2].

The general approach managing any cough begins with a search for the cause of cough and treatment of the underlying cause. However, to recognize the origin 
Table 1 Characteristics of clinical studies comparing levodropropizine to controls in children

\begin{tabular}{|c|c|c|c|c|c|}
\hline Study & Design & Participants & $\begin{array}{l}\text { Intervention vs. } \\
\text { comparator }\end{array}$ & Condition & Outcomes \\
\hline $\begin{array}{l}\text { De Blasio } \\
2012\end{array}$ & Observational study & $\begin{array}{l}\text { Children } \mathrm{N}=433 \text { (161 valid for analysis) } \\
\text { Mean age: 6,1 yrs }\end{array}$ & $\begin{array}{l}\text { Levodropropizine } \\
\text { vs. cloperastine/ } \\
\text { codeine }\end{array}$ & $\begin{array}{l}\text { Acute cough } \\
\text { associated with a } \\
\text { URTI }\end{array}$ & $\begin{array}{l}\text { Cough severity } \\
\text { reduced by all } \\
\text { antitussives }\end{array}$ \\
\hline Kim 2002 & $\begin{array}{l}\text { RCT double-blind, two } \\
\text { parallel groups Oral } \\
\text { administration t.i.d. for } \\
3 \text { days }\end{array}$ & $\begin{array}{l}\text { Children } \mathrm{N}=77 \text { (75 valid for analysis) Mean } \\
\text { age: } 3 \text { yrs }\end{array}$ & $\begin{array}{l}\text { Levodropropizine } \\
\text { vs. } \\
\text { dextromethorphan }\end{array}$ & $\begin{array}{l}\text { Acute or chronic } \\
\text { bronchitis with } \\
\text { non-recurrent or } \\
\text { slightly recurrent } \\
\text { cough }\end{array}$ & $\begin{array}{l}\text { Improvement in } \\
\text { cough frequency and } \\
\text { severity significantly } \\
\text { higher with } \\
\text { levodropropizine }\end{array}$ \\
\hline $\begin{array}{l}\text { Banderali } \\
1995\end{array}$ & $\begin{array}{l}\text { RCT double-blind, double- } \\
\text { dummy, prospective, two } \\
\text { parallel groups, Oral } \\
\text { administration t.i.d. for } \\
3 \text { days }\end{array}$ & $\begin{array}{l}\text { Children } N=267 \text { (258 valid for analysis) Age: } \\
2-14 \text { yrs }\end{array}$ & $\begin{array}{l}\text { Levodropropizine } \\
\text { vs. dropropizine }\end{array}$ & $\begin{array}{l}\text { Non-productive } \\
\text { cough }\end{array}$ & $\begin{array}{l}\text { Significant decrease in } \\
\text { cough frequency and } \\
\text { night awakenings } \\
\text { with both treatment }\end{array}$ \\
\hline $\begin{array}{l}\text { Fiocchi } \\
1991\end{array}$ & $\begin{array}{l}\text { RCT double-blind, Oral } \\
\text { administration in single } \\
\text { dose for } 4 \text { weeks }\end{array}$ & Children $N=12$ Age: $2-8$ yrs & $\begin{array}{l}\text { Levodropropizine } \\
\text { vs. placebo }\end{array}$ & Asthmatic cough & $\begin{array}{l}\text { Significant reduction } \\
\text { in nocturnal } \\
\text { awakening with } \\
\text { levodropropizine }\end{array}$ \\
\hline
\end{tabular}

of cough is not always an easy task and, even when identified, cough is refractory to specific therapy in a significant number of patients [1]. Furthermore, empiric treatment with antitussive agents is often needed, in particular when associated with deterioration in the quality of life $[1,2]$.

The etiology of cough in children differs from that in adults: viral URTI, protracted bacterial bronchitis and asthma are frequently the cause of cough [2] in children. So, the empirical approach commonly used in adults is unsuitable for children. Clinical evaluation of cough in children should also include an assessment of environmental factors, particularly tobacco smoke, parental concerns and expectations [4].

Two types of antitussive drugs are mainly available for the management of cough: centrally acting (opioids and non-opioids) cough suppressants and peripheral antitussives. Codeine, dextromethorphan and cloperastine are among the most common central agents that inhibit cough primarily by their effect on the cough center. Levodropropizine is a non-opioid agent whose peripheral antitussive action may result from its modulation of sensory neuropeptide levels within the respiratory tract [5]. In particular, levodropropizine exerts its antitussive effect through an inhibitory action at the level of the airway sensory nerves and it has been shown to be able to inhibit in vitro the release of neuropeptides from $\mathrm{C}$-fibers [6]. In addition, in anaesthetized cats, it markedly reduces the activation of $\mathrm{C}$-fibres and abolishes the associated reflexes [7]. The activity of levodropropizine on airway sensory units other than the C-fibres has not been investigated.

Centrally acting cough suppressants, although largely used, may achieve antitussive activity at the expense of unpleasant or intolerable side effects in adults and serious adverse events in children: side effects like drowsiness, dependency, loss of awareness, insomnia and difficulty in breathing [2].

Furthermore, the efficacy of most antitussive drugs, particularly those for URTI, has been challenged recently; in fact, the American College of Chest Physicians (ACCP) advises against the use of antitussive drugs in URTI [2].

Thus, the aim of the present study was to make a meta-analysis of clinical studies of levodropropizine vs. control drugs to evaluate the overall comparative efficacy of levodropropizine in the pediatric and adult population.

Table 2 Characteristics of clinical studies comparing levodropropizine to controls in adults

\begin{tabular}{|c|c|c|c|c|c|}
\hline Study & Design & Participants & $\begin{array}{l}\text { Intervention vs. } \\
\text { comparator }\end{array}$ & Condition & Outcomes \\
\hline $\begin{array}{l}\text { Allegra } \\
1988\end{array}$ & $\begin{array}{l}\mathrm{RCT} \text {, double-blind Oral } \\
\text { administration t.i.d. for } 3 \text { days }\end{array}$ & $\begin{array}{l}\text { Adults } N=40 \text { Age: } \\
>13 \text { yrs }\end{array}$ & $\begin{array}{l}\text { Levodropropizine } \\
\text { vs. placebo }\end{array}$ & $\begin{array}{l}\text { Bronchitis } \\
\text { cough }\end{array}$ & $\begin{array}{l}\text { Higher reduction in cough severity with } \\
\text { levodropropizine }\end{array}$ \\
\hline $\begin{array}{l}\text { Catena } \\
1997\end{array}$ & $\begin{array}{l}\mathrm{RCT} \text {, double-blind, double- } \\
\text { dummy, two parallel groups Oral } \\
\text { administration t.i.d. for } 5 \text { days }\end{array}$ & $\begin{array}{l}\text { Adults } N=209 \\
\text { Age: } 18-75 \text { yrs }\end{array}$ & $\begin{array}{l}\text { Levodropropizine } \\
\text { vs. } \\
\text { dextromethorphan }\end{array}$ & $\begin{array}{l}\text { Moderate } \\
\text { non- } \\
\text { productive } \\
\text { cough }\end{array}$ & $\begin{array}{l}\text { Significant reduction in cough frequency with } \\
\text { both treatments; Levodropropizine significantly } \\
\text { more effective in reducing nocturnal } \\
\text { awakenings }\end{array}$ \\
\hline $\begin{array}{l}\text { Luporini } \\
1998\end{array}$ & $\begin{array}{l}\text { RCT, double-blind, two parallel } \\
\text { gropus Oral administration t.i.d. } \\
\text { for } 7 \text { days }\end{array}$ & $\begin{array}{l}\text { Adults } N=140> \\
18 \text { yrs }\end{array}$ & $\begin{array}{l}\text { Levodropropizine } \\
\text { vs. dihydrocodeine }\end{array}$ & $\begin{array}{l}\text { Lung cancer } \\
\text { cough }\end{array}$ & $\begin{array}{l}\text { Significant reduction in cough severity and } \\
\text { nocturnal awakenings with both treatments }\end{array}$ \\
\hline
\end{tabular}


Table 3 Absolute and standardized mean delta (levodropropizine vs. controls)

\begin{tabular}{|c|c|c|c|c|c|c|c|c|c|c|}
\hline \multirow[t]{2}{*}{ Studies, parameters } & \multicolumn{3}{|c|}{ Levodropropizine } & \multicolumn{3}{|l|}{ Controls } & \multirow{2}{*}{$\begin{array}{l}\text { Standardized } \\
\text { Mean Delta }\end{array}$} & \multicolumn{2}{|c|}{ C.I. $95 \%$} & \multirow[t]{2}{*}{$p$} \\
\hline & Mean Delta & SD & $\mathbf{N}$ & Mean Delta & SD & $\mathbf{N}$ & & Lower & Upper & \\
\hline Banderali, frequency & -8.4 & 17.3 & 130 & -7.7 & 13.7 & 126 & -0.045 & -0.291 & 0.202 & 0.7216 \\
\hline Dong Soo, frequency & -1.3 & 1.14 & 38 & -0.7 & 1.12 & 37 & -0.525 & -0.996 & -0.055 & 0.0290 \\
\hline Banderali, nocturnal awakenings & -1.0 & 2.55 & 132 & -1 & 2.46 & 126 & 0.000 & -0.246 & 0.246 & 1.0000 \\
\hline Fiocchi, nocturnal awakenings & -1.06 & 0.81 & 12 & -0.46 & 0.74 & 12 & -0.747 & -1.639 & 0.146 & 0.0966 \\
\hline DongSoo, severity & -1.2 & 1.0 & 38 & -0.7 & 0.99 & 37 & -0.495 & -0.967 & -0.028 & 0.0382 \\
\hline De Blasio, severity & -1.58 & 0.96 & 101 & -1.1 & 1.13 & 60 & -0.465 & -0.792 & -0.139 & 0.0055 \\
\hline Catena, frequency & -8.3 & 7.5 & 110 & -8.2 & 7.75 & 99 & -0.013 & -0.287 & 0.260 & 0.9250 \\
\hline Catena, nocturnal awakenings & -2.7 & 1.8 & 80 & -2.12 & 1.8 & 79 & -0.321 & -0.637 & -0.005 & 0.0466 \\
\hline Luporini, nocturnal awakenings & -1 & 1.5 & 34 & -1 & 1.4 & 29 & 0.0 & -0.508 & 0.508 & 1.0000 \\
\hline Allegra, severity & -1.55 & 1 & 20 & -0.8 & 1.11 & 20 & -0.696 & -1.362 & -0.030 & 0.0410 \\
\hline Luporini, severity & -1.2 & 2.92 & 58 & -1.2 & 3.2 & 65 & 0.0 & -0.358 & 0.358 & 1.000 \\
\hline
\end{tabular}

\section{Methods}

Literature search and study selection

A comprehensive systematic literature search was carried out on the main scientific electronic databases (PubMed/ MEDLINE, EMBASE, and Cochrane Library) from their inception throughout May 2014, to identify original clinical studies of levodropropizine for the treatment of cough in the pediatric and adult settings. We sought additional articles from reference lists of review articles.

The inclusion criteria used to select studies were established a priori. Only studies with a controlled design (vs. both active control and placebo), including pediatric and adult patients and assessing efficacy endpoints related to cough outcomes, were selected.

Out of all the studies identified by means of our systematic literature search a total of 7 published clinical studies conducted with levodropropizine in adults or children met the eligibility criteria and were selected for our meta-analysis.

These studies included a total population of 1,178 patients: four studies included 789 children and three studies included a total of 389 adults.

Levodropropizine was compared with central antitussive in five studies [8-12] and against a placebo in two studies $[13,14]$.

\section{Data analysis}

Due to the small number of clinical trials in the pediatric and adult population and the different clinical endpoints, the efficacy outcomes of the selected studies were standardized

Table 4 Meta-analysis of overall antitussive efficacy (levodropropizine vs. controls)

\begin{tabular}{lclll}
\hline $\begin{array}{l}\text { Levodropropizine } \\
\text { versus Controls }\end{array}$ & $\begin{array}{l}\text { Standardized } \\
\text { Mean Delta }\end{array}$ & \multicolumn{2}{l}{ C.I. 95\% } & p \\
\cline { 3 - 4 } & Lower & Upper & \\
\hline & -0.176 & -0.282 & -0.069 & 0.0015 \\
\hline
\end{tabular}

in order to compare the overall efficacy of levodropropizine versus control groups. Thus, the meta-analysis was performed after standardization of the overall efficacy variables assessed as endpoints in the eligible studies (i.e. reduction in cough frequency and severity, and number of night awakenings). For all the studies, original Absolute Mean Delta was calculated as the mean differences between baseline and final values of efficacy parameters in both groups, with the respective (approximate) standard deviations (SD) and the number of cases (N) studied in single treatment groups [15]. Standardized Mean Delta was calculated by means of the original Absolute Mean Delta (with their SD and N) and indicates a fraction or multiple of unitary standard deviations, expressed as standardized units $[16,17]$.

\section{Characteristics of included studies}

The study of De Blasio et al. [10] was an observational one, carried out in 433 children (mean age 6 years) whose aim was to evaluate the efficacy of antitussive drugs in reducing the severity of acute cough associated with a URTI. A subgroup of 161 children received antitussive treatment with levodropropizine $(\mathrm{N}=101)$ or central cough suppressants (codeine or cloperastine, $\mathrm{N}=60$ ).

In a double blind, two parallel groups, randomized study carried out by Kim et al. [11], the efficacy of levodropropizine was compared to the central antitussive dextromethorphan in 77 children (mean age 3 years) with acute or chronic bronchitis with non-recurrent or slightly recurrent cough treated for 2-3 days (oral t.i.d. administration). In a double blind, double-dummy, two parallel groups, randomized study Banderali et al. [8] evaluated the efficacy of levodropropizine compared to dropropizine, administered orally t.i.d. for 3 days, in the management of non-productive cough in 267 pediatric patients (2-14 years old). 
The efficacy of levodropropizine vs. placebo in single oral dose for 4 weeks on nocturnal cough was investigated by Fiocchi et al. in a small double blind randomized study in 12 children with asthma [14]. In a double blind, two parallel groups, randomized study [12], Luporini et al. evaluated the efficacy of levodropropizine compared to dihydrocodeine (oral t.i.d. administration for 7 days) in the treatment of non-productive cough in 140 adults with primary lung cancer or metastatic cancer of the lungs. The double blind, double-dummy, parallel groups, randomized trial of Catena et al. [9], evaluated the therapeutic efficacy of levodropropizine compared to dextrometrorphan, administered orally t.i.d. for 5 days in 209 adults with moderate non-productive cough. The efficacy of levodropropizine vs. placebo (oral t.i.d administration for 3 days) on cough severity in 40 adult patients with bronchitis was evaluated in a double blind,randomized, clinical trial carried out by Allegra et al. [13]. The main characteristics of published studies evaluating the antitussive efficacy of levodropropizine vs. control in children and adults are summarized in Tables 1 and 2, respectively.

\section{Results}

Table 3 shows the original Absolute Mean Delta (with SD and N) calculated for each efficacy parameter (cough frequency, cough severity, and night awakenings) assessed in each of the eligible clinical studies, both in levodropropizine and control groups in pediatric and adult patients.

The results of the standardization of different efficacy variables, in order to make them comparable, are also shown in Table 3 as Standardized Mean Delta (with 95\% C.I. and p between treatment groups).

The results of the meta-analysis of all standardized parameters, representing overall antitussive efficacy, showed a highly statistically significant difference in efficacy in favor of levodropropizine versus control treatments (including central cough suppressants), with $\mathrm{p}$ of 0.0015 (Table 4). The size of antitussive effect of levodropropizine vs. control treatments in the pediatric and adult setting is shown in the overall efficacy meta-analysis chart (Figure 1).

Concerning the estimated efficacy outcomes, levodropropizine was superior or equal to controls in all 7 clinical studies, also reaching a statistically significant difference $(\mathrm{p}<0,05)$ in 4 studies.

In our meta-analysis, the test of heterogeneity for the efficacy outcome was not statistically significant $(\mathrm{p}=0.0534)$.

\section{Discussion}

Cough remains a serious unmet clinical problem [2]. It is a symptom of a range of diseases such as asthma, chronic obstructive pulmonary disease, GERD, or other conditions of unknown origin [2].

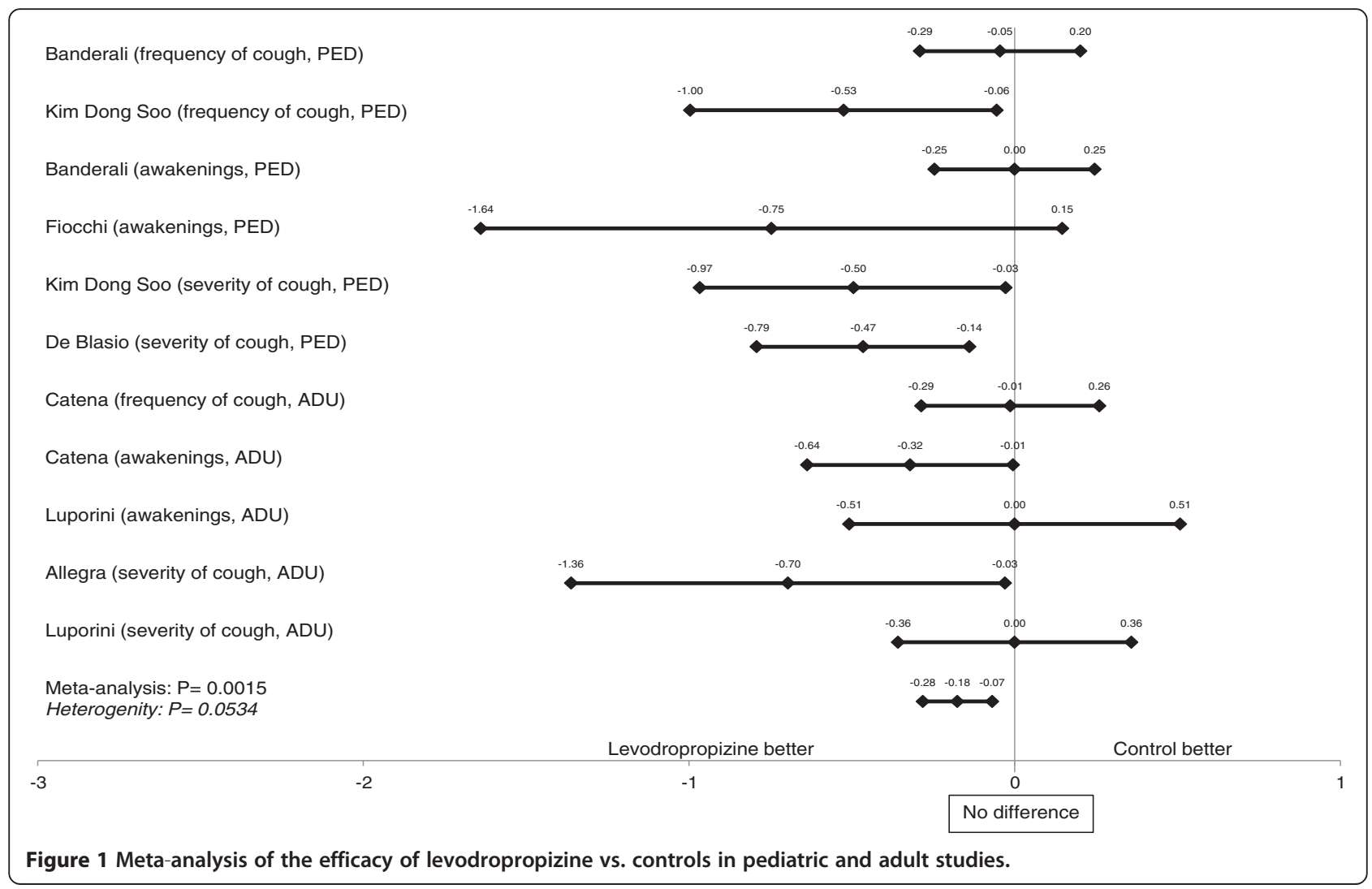


Managing the symptom of cough, regardless of whether the etiology is known, is also a challenge to even the most experienced health care provider [1].

The American College of Chest Physicians (ACCP) guidelines also recommend the use of peripheral cough suppressants such as levodropropizine in adult patients with cough due to acute or chronic bronchitis for the short-term symptomatic relief. These guidelines state that levodropropizine related to therapy of acute or chronic bronchitis has got the highest level of benefit, while the central antitussive drugs such as codeine and dextromethorphan show a lower level of benefit [18].

Recently, the European Medicines Agency (EMA) started a review of codeine-containing medicines when used for cough and cold in children. In fact, codeine is converted into morphine by CYP2D6 enzyme. It is well-known that some patients defined as 'CYP2D6 ultra-rapid metabolizers' convert codeine to morphine at a faster rate, resulting in higher levels of morphine in their blood leading to toxic effects such as breathing difficulties. EMA is still evaluating the available evidence on the benefit-risk balance of codeine-containing medicines when they are used for cough and cold in children [19]. FDA and MHRA recommended against the use of OTC products for cough and colds, as central antitussives in infants and young children and the American Academy of Paediatrics has advised against using dextromethorphan and codeine for treating cough in the pediatric population [20].

The major efficacy of levodropropizine in comparison to central antitussives has been recently demonstrated in a meta-analysis considering only children with cough of various origin (10).

This standardized meta-analysis of 7 published clinical studies, despite some limitations mainly linked to the small number of trials included in the analysis and the different efficacy variables assessed, provides an overview of the major comparative studies on levodropropizine in terms of efficacy both in the pediatric and adult setting, demonstrating a higher efficacy of levodropropizine.

\section{Conclusions}

Levodropropizine is an effective antitussive drug both in children and adults, showing statistically significant better outcomes vs. central antitussive drugs in terms of overall efficacy in reducing cough intensity, frequency and night awakenings.

These positive results are particularly important considering that levodropropizine is a very well tolerated peripheral antitussive drug, while centrally-acting cough suppressants may be associated with serious side effects that limit their use, thus further reinforcing the favorable benefit/risk profile of levodropropizine in the management of cough.

\section{Competing interests}

Lanata and Saibene are employees of Dompé SpA, Medical Department. Dompé SpA is a company that manufactures and commercializes levodropropizine. Dicpinigaitis has served as a consultant to Dompe. De Blasio has been member of an International Advisory Group supported by an unrestricted educational grant of Dompé SpA. Moreover, he received speech honoraria from Dompé SpA at National as well International meetings. Giovanni Fontana received research grants or fees from Menarini, Edmond Pharma, Dompé Vertona Pharma, AMD.

\section{Authors' contributions}

All authors carried out the literature review. All authors carried out the draft paper. All authors read and approved the final manuscript.

\section{Acknowledgements}

The authors would like to thank B Chinea, D Ferrari (Ibis Informatica srl) for their statistical support.

\section{Author details}

'Pneumology Unit, University of Bologna, S. Orsola Malpighi Hospital, Bologna, Italy. ${ }^{2}$ University Hospital Careggi, Florence, Italy. ${ }^{3}$ Medical Department, Dompé SPA, Milan, Italy. ${ }^{4}$ Respiratory Medicine and Pulmonary Rehabilitation Section, Clinic Center, Private Hospital, Naples, Italy.

${ }^{5}$ Department of Medicine, Albert Einstein College of Medicine and Montefiore Medical Center, Bronx, NY, USA.

Received: 21 October 2014 Accepted: 22 April 2015

Published online: 31 May 2015

\section{References}

1. De Blasio F, Virchow JC, Polverino M, Zanasi A, Behrakis PK, Kilinç G, et al. Cough management: a practical approach. Cough. 2011;7:7.

2. Dicpinigaitis PV, Morice AH, Birring SS, McGarvey L, Smith JA, Canning BJ, et al. Antitussive drugs-past, present, and future. Pharmacol Rev. 2014;66:468-512.

3. Nasra J, Belvisi MG. Modulation of sensory nerve function and the cough reflex: understanding disease pathogenesis. Pharmacol Ther. 2009;124:354-75.

4. De Blasio F, Lanata L, Dicpingaitis PV, Saibene F, Balsamo R, Zanasi A. Efficacy of levodropropizine in the pediatric setting: a meta-analysis of published studies. Trends Med. 2013;13:9-14.

5. Dicpinigaitis PV. Current and future peripherally-acting antitussives. Resp Physiol Neurobiol. 2006;152:356-62.

6. Lavezzo A, Melillo G, Clavenna G, Omini C. Peripheral site of action of levodropropizine in experimental-induced cough: role of sensory neuropeptides. Pulm Pharmacol. 1992;5:143-7.

7. Melillo G, Malandrino S, Rossoni G, Caselli G, Bestetti A, Borsa M, et al. General pharmacology of the new antitussive levodropropizine. Arzneimittelforschun. 1998:38:1144-50.

8. Banderali G, Riva E, Fiocchi A, Cordaro Cl, Giovannini. Efficacy and tolerability of levodropropizine and dropropizine in children with non-productive cough. J Int Med Res. 1995;23:175-83

9. Catena E, Daffonchio L. Efficacy and tolerability of levodropropizine in adult patients with non-productive cough, Comparison with dextromethorphan. Pulm Pharmacol Ther. 1997;10(2):89-96.

10. De Blasio F, Dicpinigaitis PV, De Danieli G, Lanata L, Zanasi A. Efficacy of levodropropizine in pediatric cough. Pulm Pharmacol Ther. 2012;25:337-42.

11. Kim DS, Sohn MHMD, Jang GC. Levodropropizine in children with bronchitis. Diagn Treat. 2002;22:9.

12. Luporini G, Barni S, Marchi E, Daffonchio L. Efficacy and safety of levodropropizine and dihydrocodeine on non-productive cough in primary and metastatic lung cancer. Eur Res J. 1998;12(1):97-101.

13. Allegra $L$, Bossi R. Clinical trials with the new antitussive levodropropizine in adult bronchitic patients. Arzneimittelforschung. 1988;38(8):1163-6.

14. Fiocchi A, Arancio R, Murgo P, Banderali G. Levodropropizine effectiveness on nocturnal cough in asthmatic children. Eur Res J. 1991;4(14):594.

15. Sutton $A J$, Abrams $K R$, Jones $D R$, Sheldon $T A$, Song F. Methods for meta-analysis in medical research. Chichester UK: John Wiley \& Sons Ltd.; 2000.

16. Armitage P, Berry G, Matthews JNS. Statistical methods in medical research. 4th ed. Oxford, England: Blakwell Scientific Publications; 2002. 
17. Hedges LV, Olkin I. Statistical methods for meta-analysis. New York: Academic Press; 1985.

18. American Academy of Pediatrics. Committee on Drugs: Use of codeine and dextromethorphan-containing cough remedies in children. Pediatrics. 1997;99:918-20.

19. Start of review of codeine-containing medicines when used for cough and cold in children. [http://www.ema.europa.eu/ema/index.jsp?curl=pages/ news_and_events/news/2014/04/ news_detail_002072.jsp\&mid=WC0b01ac058004d5c1]

20. Irwin RS, Baumann MH, Bolser DC, Boulet LP, Braman SS, Brightling CE, et al. American College of Chest Physicians (ACCP): Diagnosis and management of cough executive summary: ACCP evidence-based clinical practice guidelines. Chest. 2006;129:1S-23S.

\section{Submit your next manuscript to BioMed Central and take full advantage of:}

- Convenient online submission

- Thorough peer review

- No space constraints or color figure charges

- Immediate publication on acceptance

- Inclusion in PubMed, CAS, Scopus and Google Scholar

- Research which is freely available for redistribution 